\title{
Aërial Navigation
}

\section{A. Silva White Hon. F.E.S.G.S.}

To cite this article: A. Silva White Hon. F.E.S.G.S. (1896) Aërial Navigation, Scottish Geographical Magazine, 12:6, 290-298, DOI: 10.1080/00369229608732886

To link to this article: http://dx.doi.org/10.1080/00369229608732886

曲 Published online: 27 Feb 2008.

Submit your article to this journal $\widetilde{3}$

III Article views: 5

Q View related articles ¿ 


\section{AËRIAL NAVIGATION.}

\section{By A. Silva White, Hon. F.R.S.G.S.}

To navigate the atmosphere as the mariner navigates his ship has been the dream of countless enthusiasts. Records reach us from the Middle Ages, and even earlier times, of flying men and flying-machines. But, from the classic fables of Dædalus and Icarus and "the dove of Archytas" down to the adventurous attempt of the Italian alchemist who, in the early part of the sixteenth century, endeavoured to fly from the walls of Stirling Castle, it is difficult to discover where fact ends and fiction begins. The problem of aërial navigation has, however, at last passed into the hands of competent investigators, who are confident that its solution will be successfully accomplished before the close of the current century.

The art of aërostation has a curious history. The year 1783 is the annus mirabilis in the science of aëronautics: it records the construction at Annonay, near Lyons, of the first balloon. The brothers Montgolfier, sons of a famous papermaker at Annonay, were the discoverers. It occurred to them that, if they could obtain any vapour lighter than air and enclose it in a large bag, the same natural law which sustained the clouds in the heavens would raise their simple contrivance to similar heights.' So, taking a leaf from the open book of nature, they constructed a paper balloon with their skilled hands. In order to reproduce "clouds," they lighted chopped straw and caught the smoke. And the balloon rose into the air!

This successful experiment created the greatest enthusiasm throughout Europe. It was repeated on the 19 th September 1783 , by the Montgolfiers, before a brilliant assemblage of the French Court at Versailles. On this important occasion the balloon rose 1500 feet, and descended after being in the air for eight minutes. Attached to the balloon was a cage containing the first aërial travellers-a sheep, a cock, and a duck.

The brothers Montgolfier believed it was the smoke that raised their paper balloon; and it was only subsequently recognised that the ascensional power was due merely to the lightness of heated air as compared with an equal volume at a lower temperature. The difficulty of generating heàted air was overcome by fixing a brazier containing ignited matter under the neck of the balloon, which was thereby sustained as long as the fire lasted, and was enabled, besides, to carry human freight.

In spite of the Montgolfiers' discovery of the fire-balloon, perhaps greater credit was due to Professor Charles, of Paris, who, shortly after the experiments at Annonay, used hydrogen gas (then known as "inflammable air") as the ascensional power. Professor Charles constructed a balloon which differed very little from those in use at the present day: it was made of silk, varnished over with an elastic gum, and had not only the netting and hoop as now used, but also the escape-valve at the top.

Both in this gas-balloon of Professor Charles and in the fire-balloon 
of the Montgolfiers several personal ascents were made; and they were imitated all over Europe. The first personal ascent in Britain was made from Comely Gardens, Edinburgh, on the 27 th August 1784, when Mr. Tytler rose in a fire-balloon of his own construction; but, as the balloon was not provided with fuel, it descended half-a-mile from the place of starting. This achievement Mr. Tytler modestly called " a leap into the air"; and he very courteously surrendered the credit of "the first personal ascent in Britain" to Lunardi, whose feats a few days later created the utmost enthusiasm in London.

To Mr. Charles Green was due the substitution of coal gas for hydrogen gas. Since his first ascent on 19 th July 1821, this gas has almost invariably been employed for balloons.

All kinds of balloons have since been constructed; but, saving the improvements of a few minor details in their gear, no real progress has been made. We have, it is true, a Balloon Society, at whose meetings every subject under the sun-except balloons-is discussed; and every year a large number of patents for flying-machines are registered : but, until quite recently, practically no progress has been made in solving the problem of aërial navigation. The balloon itself has been used chiefly as a toy to fascinate the public mind. Sometimes it has been put to practical use, as at the siege of Paris, when balloons were the only means by which communication with the outside world could be maintained, and by which some of the besieged, notably Gambetta, effected their escape. Moreover, in nearly all the more recent wars, a balloon corps has rendered important services by spying out the movements of the enemy : consequently, nearly every European army, and especially the French, maintains a carefullytrained corps equipped for this service. For scientific purposes, too, the balloon offers incalculable advantages; but, though many useful contributions have been made to meteorology and the physical sciences by competent observers and aëronauts, the cost of conducting a series of systematic synchronous observations is too great to popularise the employment of this agency.

For the practical purposes of aërial navigation the balloon has been proved, over and over again, to be quite inadequate. So-called " navigable balloons" have frequently been constructed, more or less on the same lines as $L a$ France, the most successful of all the inventions in that direction. The shape of $L a$ France resembled that of a fish or a cigar, and it was propelled by a screw, the driving power of which was derived from an electric motor. The advance in our knowledge of electricity has, in fact, opened ont new prospects to inventors of flying-machines, for it has long been recognised by engineers and scientific experts that the solution of the problem of aviation, or flying in the air, rested on the discovery of a motor which should have "sufficient energy in proportion to its weight." "This motor," Mr. Hiram Maxim now asserts, "has been found, its power has been tested, and its weight is known." But it has been proved to demonstration that the ascensional power must come from the machine itself, and not depend on the lifting capacity of the balloon in any shape or form : since it is impossible to drive an inflated envelope against the impact of the wind. This principle may be made clearer to the reader if 
I describe some of my own humble experiments in the utilisation of aircurrents in ballooning.

In the present state of aëronautics it would be of some value to know how far it is possible for a balloon to utilise air-currents in order to reach a definite goal. Clumsy as is the balloon for the purpose of aërial navigation, I know that much may be accomplished by a capable steersman. It is useless to attempt to guide, by any contrivance whatever, the balloon as it is constructed at the present day. Immersed totally. in the elastic fluid of the atmosphere, it is not possible to overcome the lateral resistance of the wind. Vertical gravity is overcome by an imprisoned gas, lighter than the surrounding fluid, which ascends until it establishes an equilibrium-that is to say, until the weight of the floating body is equal to the weight of the fluid atmosphere it displaces. The inherent force or contrivance for resisting the impact of the wind has, therefore, still to be perfected, as no doubt it will be, judging from the tentative experiments with Mr. Maxim's aëroplane. Hence, flyingmachines and not balloons will be the future navigators of the aërial ocean.

Anybody who has witnessed a balloon filling during the prevalence of a high wind must have felt convinced of the impossibility of any conceivable agency being capable of driving such a light body against it; and even if this were in a measure possible, the light material of which the balloon is necessarily constructed would not stand the friction. Those cases in which a certain measure of success has been reported, of " navigable balloons" going within a few points of the wind, are more likely attributable to the influence of the cross-currents that everywhere are met with in the higher, and often in the lower, strata of the atmosphere. The surface wind prevails sometimes no higher than 500 feet; but it has also been found constant at as great an altitude as four miles. An intelligent use of the air-currents, therefore, would enable the aëronaut, within certain restrictions and under favourable conditions, to guide his balloon.

Formerly, in the early stages of scientific inquiry, it was thought that the atmosphere surrounding our globe was of no great depth, and that it might be possible to raise a body to its uppermost limits-as a cork floats to the surface of a basin of water-where, having two mediums instead of one, the atmosphere might be navigated like the ocean. But in the light of established science, the analogy between the navigation of the ocean and that of the air-an inelastic and an elastic fluid-has been shown to be false. A balloon floating in the air is at the sport of the wind, and the only way of navigating it is to fall in with favourable aircurrents. It is true that our knowledge of air-currents is most imperfect; but meteorology is a young science, and aëronautics is still in its infancy. Only by constant and comprehensive experiments, therefore, can we hope to discover reliable "sailing directions" for the balloonists of the future.

As far as I am aware, little or no attention has been given to this aspect of ballooning. This is the more surprising, because one would have thought that a single ascent would be sufficient to impress on 
the mind of the aëronaut the great part played by air-currents in the guidance of his balloon. At least, this was my experience; and I immediately set myself the task-though in a very limited way-of ascertaining how far air-currents might be relied on.

Taking advantage, ten years ago, of the visit to Edinburgh of $\mathrm{Mr}$. Dalewho, it will be remembered, was killed in a balloon accident at the Crystal Palace-I conducted a series of experiments, some of which yielded decisive results. Mr. Dale's balloon, the Edina, was a new one, though with a capacity of only 28,000 feet of gas. It had a diameter of thirtyeight feet, and measured with the car sixty feet in height. Thus, our scope for experimental ballooning was extremely limited, owing to the small size of the balloon and its consequent want of power. The Edina was able to carry only two persons and a very small supply of ballast.

My first ascent with Mr. Dale was on September 26th, 1886. The wind was blowing from the south-west, veering occasionally to the south; but the surface current, as shown by the ultimate course taken by the balloon, and ascertained beforehand by a small "pilot-balloon," was due south. The Edina, on being released, rose perpendicularly to 500 feet, where she obtained an equilibrium, aud was driven by an undercurrent in a north-easterly direction. By easing her of the weight of some ballast, the balloon rose to 1500 feet, where she met the true and constant surface wind from the south. We therefore commenced the passage of the Firth of Forth in a northerly direction. About half-way across, the draught drawing down the Firth slightly altered the balloon's course, setting her about a mile to leeward, but the danger of being blown seawards was easily obviated by raising the balloon to 2000 feet, and ultimately to 2500 feet, above the influence exercised by the physical formation of the land. The passage of the Firth was accomplished under a heavy shower of rain in fifteen minutes, at a speed of twenty miles an hour. Skirting the Fife coast, a landing was effected two miles north of Kirkcaldy.

I have given some particulars of this ascent in order that the reader may note two things - the action of air-currents in determining the course of the balloon, and the ease with which, under favourable circumstances, these may be utilised by an intelligent aëronaut. Of course it may happen that the prevailing wind may be constant for a considerable altitude ; but, still, it is rare that a divergent or even contrary current may not be found by a balloon of large capacity. I remember reading of a French aëronaut who, ascending from Calais during a high wind, was blown straight out to sea, but returned to his starting-point by a contrary wind, which, happily, he found by mere accident at a great altitude.

By a careful study of the weather, and the means which the aëronaut has of ascertaining the direction of the wind both before and during an ascent, it is quite possible to place a fair amount of reliance on the direction which the balloon may ultimately take. In several of the ascents made by Mr. Dale at Edinburgh, I was able to ascertain beforehand the approximate course of his balloon, and also the places at which a landing might be effected. The most successful of these experiments 
was on the occasion when he reached Kinross, twenty-one miles distant from Edinburgh, in three-quarters of an hour. This spot I had fixed on several hours before the ascent was made: and it was gained only by seeking out the most favourable air-currents, for the prevailing wind would have taken the balloon considerably to the east. A steady breeze from the south-east, with an area of low-pressure skirting our northwestern shores, causing the upper air-currents to veer between southeast and south-south-west, offered to the aëronaut the choice of a number of places in Fifeshire located within a vast triangle (the apex of which was the starting-point) at which a landing might have been effected. Owing to the short distance which a balloon of such limited capacity as the Edina could safely accomplish, the easiest spot was chosen for a goal: for to manouvre the balloon requires a large expenditure of its very life-blood, gas and ballast, and only very large balloons have much of either to spare.

In the other ascents I made with Mr. Dale (partly with the purpose of making physical observations), untoward circumstances prevented any adequate tests being applied, but their partial failure was not without instructive results.

On one occasion we arranged a race between two balloons. $\mathrm{Mr}$. Dale and I were in one-the Sunbeam-and Captain Taylor was alone in the Edina. The race caused a considerable amount of public interest, because, $I$ believe, it was the first time on record of an attempt being made by two balloons to race towards a fixed goal. It failed because the pressure of gas at the meters where the balloons were filled was insuffcient to inflate both of them at the same time, the wind being high and a good deal of gas escaping in consequence. The result was that the balloons were released with only sufficient gas and ballast to keep them above the house-tops; and, as the wind was blowing directly out to sea, it would have been impossible for the balloons, thus crippled, to have accomplished the passage of the Firth. A landing was therefore made in the town. A very rough landing it was too! The Edina was "rushed down "perpendicularly, in order to "fetch" the only available anchorage, on a small plot of ground between some houses. Unfortunately, we "carried away" the telegraph wires and wrecked the balloon, which was subsequently trampled to shreds by the mob.

Perhaps my most interesting ascent was on the 19 th October 1886. Our intention had been to make for Carstairs, a town in Lanarkshire, about thirty miles distant; but, on account of circumstances I shall refer to, we were able only to pass within three miles of this spot, landing at Carluke. The weather was grey and stormy when the Edina was released, with $\mathrm{Mr}$. Dale and myself in the car. Before the balloon had passed well over the town, we had already entered the clouds, at 2300 feet; and 300 feet higher we emerged into brilliant sunlight. The thermometer, which before starting had registered $60^{\circ} \mathrm{Fahr}$., then stood at $43^{\circ}$, and the temperature continued to decrease until, at an altitude of one mile, it was at the freezing-point, $32^{\circ}$. Here there was not much wind; and we had leisure to witness the shifting cloud-scene over which we hung suspended. We even ventured on a cigarette, at 
the risk of an explosion. The heavy cumulous masses, which entirely shut out the earth from our view, except here and there when they parted for a moment immediately under the balloon, formed towards the east a sea-scape : great crested waves breaking (as they appeared) against gaunt and jagged rocks, and rolling on to the distant horizon. The upper layer of these clouds was, except for these wave-forms, on a sharply-defined plane, and no vapour apparently intervened between them and the high cirrus clouds above. ${ }^{1}$ To the west, on the other hand, a very different cloud-scape was observed. There the scene was purely Arctic in character-an illusion that was heightened by the perfect stillness, and made very real by the relatively low temperature-snow-clad mountains of every shape and form casting shadows from the sun, and a rocky ice-bound coast, with the familiar ice-foot and "leads" of blue running water. The colouring of this Arctic scene, instead of resembling the low tones in the High North, partook of the splendour of an ideal landscape : pearly greys, azure or deep indigo blues, and warm-coloured fleecy snowdrifts enhanced the beauty of a scene which, in the Arctic regions, except under a refracted light, typifies the stern reality of death. At other points of the compass many of the most characteristic land-sculptures were represented in cloud-forms; and the scenes were constantly shifting; though imperceptibly to the eye. For a few moments the balloon cast the curious double shadow - that of a balloon inverted on another balloon-so often witnessed in aërial navigation. The Edina descended of her own accord into a nimbus, or rain-cloud, to avoid passing through which some ballast was thrown out; but another swift downward movement shortly afterwards took place, until, at 3800 feet, the clouds parted and the earth again became visible. We were at that moment over Cobbinshaw reservoir; and at the same mean elevation we passed at a great speed over the marshy, inhospitable moorlands to the west of the Pentland Hills. A landing was effected with much difficulty. The strong wind prevalent at the time carried the balloon, after her first contact with the earth, rapidly over two fields; but at the second hedge the car, instead of leaping over or through it, as in the first instance, caught a stout paling which held it captive until, with the assistance of several men, the balloon was safely secured. Another leap would have taken us into the midst of several blazing furnaces ; and it was this consideration which induced me to hang on to that providential paling "like grim death," in spite of Mr. Dale shouting to me, "Let go, or you will break your arm!"

On this trip we laboured under the disadvantage of having the valverope (which leads to the top of the balloon to release the gas) twisted into a knot in the very centre of the inflated envelope, so that it could be reached only by means of an umbrella attached to a stick. We had, in fact, been "sent up" in a hurry, the very car having been slung awry. Consequently, we were at the sport of the wind and were most careful

$i$ This "sea of clouds" resembled in every particular that which I viewed for a week on end whilst camping out in the old crater of Tenerife. In the North-East :Trades, the clouds round the Peak form every day with extreme regularity: one can almost tell the time by them. 
not to jeopardise our frail hold on the valve-rope by using it, except on an emergency; and so we permitted ourselves to ascend or descend as the varying temperatures affected the gas in the balloon: in the end, however, the balloon had to be ripped open in order to avert a catastrophe.

In attaining high altitudes, the fact of passing through several hundred feet of rain-cloud into the warm sunlight above, causes the gas to expand and to escape through the open neck of the balloon, thus lessening its carrying-power. The result is that, in again passing through the clouds towards the earth, condensation of the gas increases the velocity of the falling balloon to such an extent that only a liberal disposal of ballast can check the rapid descent.

Although with only these partial successes to look back upon, I am convinced that much might be done to navigate the balloon, within a few points of the prevailing wind, by the judicious use of air-currents. At the same time it must have been evident to the reader who has troubled to peruse my descriptions so far, that under no circumstances can the balloon be relied upon as offering the best mechanism for navigating the air. My own limited experiences show that, in order to accomplish this end, a flying-machine, heavier than the air, and capable of withstanding the impact of the wind, is the only promising air-ship of the future.

Inventors and discoverers, who are unable to circumvent a natural law, endeavour to utilise it. I have dwelt on the obstacle to aërial navigation presented by the impact of the wind. And it is precisely this apparent obstacle which Mr. Maxim has turned to account in the construction of his aëroplane, which, more than any other known mechanism or principle, appears to me to offer the best prospect of solving the problem of aërial navigation. This is, in the words of Professor Langley, "a mechanism designed to secure artificial flight by taking advantage of the inertia and elasticity of the air."

The problem of aviation, as the French call it, is now attracting considerable attention; and many of our leading inventors-especially in America and France-are turning their minds to its solution. Mr. Maxim's experiments have, in the first instance, been directed towards the discovery of general principles, " to ascertain the amount of energy required for flying, and also to ascertain what influence, if any, the factor of size has upon flight." The leading principle of the aëroplane has been lucidly described by Professor Langley, who says: "If, in such aërial motion, there be given a plane of fixed size and weight, inclined at such angles and moved forward at such speeds that it shall always be just sustained in horizontal flight, then the more the speed is increased the less will be the power required to support and advance it, so that there will be an increasing economy of power with each higher speed, up to some remote limit not yet attained in experiment." This principle, though directly contrary to that which obtains in all transport by land and water, is partly illustrated by the action of a skater on thin ice, which is too weak to bear his weight except he move over the surface at a great speed. 
As soon, therefore, as the means of directing this ingenious mechanism (the aëroplane or aërodrome) has been found, it may be quite possible to "navigate the air." The question of air-currents, to which $I$ have purposely alluded at some length, does not, so far as I have ascertained, appear to have entered into the calculations of $\mathrm{Mr}$. Maxim and his coadjutors: consequently I am curious to know how it is to be met. For, should the flying-machine soar up into a contrary or even diverse air-current, it is evident that the very principle of its flight will be the cause of its instant destruction, unless it be provided with some automatic mechanism which will enable it, without altering its divection, to adjust itself to the changed conditions.

We have heard a great deal within the last few months of Herr Andrée's bold project of reaching the North Pole by balloon. In the discussion which followed the reading of his paper at the late International Geographical Congress he received a certain amount of popular support, because such an attempt as he proposes to make naturally appealed to the sympathies of an English audience. For my own part, I did not deny that Herr Andree might, under the most favourable circumstances, reach the Geographical Pole. Given a strong southerly wind at starting he might attain his goal from Spitzbergen in a few hours. But how would he return? Our knowledge of the meteorology of the North Polar regions is so slight that all we can say is, that southerly (SW.-SE.) winds may possibly prevail during the month of July, when the attempt, this year, is to be made. But if this hypothesis is favourable to his reaching the Pole, it necessarily militates against his leaving it. His proposed use of a number of guide-ropes (to retard the progress of the balloon, in order to utilise a sail) might, if the wind be light, enable him to deflect his course by a few points; but in a strong wind this contrivance would not act. It would, moreover, be an added danger. Herr Andrée cannot expect to find an open sea at the Pole. The Palæocrystic ice, which he is likely to encounter, will afford the worst possible anchorage, and present many obstacles to the free use of his guide-ropes. In a strong wind, too-in spite of the probable uniformity of temperature, comparatively speaking, and the absence of night-he will find great difficulty, though he preserve his guide-ropes, in maintaining the low mean altitude necessary for their use. Long balloon voyages are difficult enough in Temperate regions, over well-known countries, but a voyage towards the North Pole is a flight into the unknown. The longest voyage ever made in a balloon (Paris to Sweden in 1871) lasted fifteen days; but Herr Andrée has to provide for one that may last, at least, thirty days-though the distance to be covered, 2000 to 2500 miles, can, of course, be traversed in less time, given ideal circumstances which are not likely to occur. Aëronauts have been totally lost in attempting the passage of the English Channel; but Herr Andrée must penetrate an uninhabited region, inimical to human life, with no prospect of returning to civilisation, should an accident occur to his balloon or should he run short of gas and ballast, except he and his companions manage to make their way back over the ice to an Eskimo or Danish settlement. Altogether, considering the unknown factors against which he will have to

VOL. XII. 
contend, and the totally inadequate capacity of the balloon for long aërial voyages, Herr Andrée's project, much as we may applaud it, must be characterised by experts as foolhardy in the extreme, even suicidal. Nobody can deny that there is an element of chance in his favour; but this is so slight that the adventure does not, in my opinion, warrant the support of scientists.

\section{THE METEOROLOGY OF CENTRAL ASIA.}

The meteorological observations made by N. M. Przhevalski during his four journeys in Central Asia have been worked up by Professor A. J. Voiekof, and published in a large volume by the Imperial Russian Geographical Society. ${ }^{1}$ To these are added observations of $M$. M. V. Pievtsof, and a review of the climate of the region by the Professor himself. We can only touch on some general questions.

The first of these is the extension of the summer rains of the Asiatic monsoon towards the north, and the limits of its principal regions-the Indian and the Chinese, or East Asiatic. In his Climate of the Monsoon Region of Eastern Asia, Professor Voiekof, on the ground of M. Przhevalski's observations during his first journey, included the Eastern Nanshan in the domain of the rainy Chinese monsoon, and stated that Northern (more correctly North-Eastern Tibet) had the climate of the monsoon, that is, received rain chiefly in summer. On his third journey Przhevalski formed the opinion that the summer moisture at the sources of the Whang-ho, at Kuku-nor, and in North-Eastern Tibet, was brought by west or west-south-westerly winds, and that in all probability the monsoon of Western India carried this moisture from beyond the Himalayas, while in the Eastern Nan-shan the summer rain came from China. Yet, on the other hand, he remarked that neither the Chinese nor the Indian monsoon reaches the Western Nan-shan, the Altyn-tag of Lob-nor, and the country south as far as the Kuen Lun, for there, notwithstanding the great altitude, the air is remarkably dry throughout the year, rendering the country a desert. When Przhevalski spent the summer of 1884 in North-Eastern Tibet, rain and snow were frequent and abundant, and he was confirmed in his opinion that the precipitation was carried thither by the southwest monsoon of the Indian Ocean.

With this opinion Professor Voiek of is unable to agree, for the winds in the great plain of the Ganges, in the Eastern Punjab, and on the slopes of the Himalayas, blow from the east-south-east, proceeding, therefore, from the Bay of Bengal and not from the Arabian Sea. Hence the westsouth-westerly winds of Tibet cannot be a direct extension of the Indian monsoon passing over the Western Himalayas. Moreover, if such were the source of the precipitation of North-Eastern Tibet, it would be diff-

1 Scientific Results of the Journeys of N. M. Przheralski in Central Asia. Meteorological Section. Edited by A. J. Voiekof. St. Petersburg, 1895. (In Russian. Remarks accompanying the meteorological tables in French also.) 